\title{
Effects of Rice Straw Application on Methane Emission from Rice Paddy Fields
}

\section{KIM, Su-Hun}

Department of Bio-Environmental Chemistry, College of Agriculture and Life science, Chungnam National University I Science for Bioproduction Environment, Faculty of Agriculture, Kyushu University

\section{LEE, Jae-Han}

Department of Bio-Environmental Chemistry, College of Agriculture and Life science, Chungnam National University | Science for Bioproduction Environment, Faculty of Agriculture, Kyushu University

\section{LIM, Ji-Sun}

Department of Bio-Environmental Chemistry, College of Agriculture and Life science, Chungnam National University | Science for Bioproduction Environment, Faculty of Agriculture, Kyushu University

\section{SHINOGI, Yoshiyuki}

Science for Bioproduction Environment, Faculty of Agriculture, Kyushu University I Science for Bioproduction Environment, Faculty of Agriculture, Kyushu University

他

https://doi.org/10.5109/1955658

出版情報：九州大学大学院農学研究院紀要. 63 (2)，pp.387-392，2018-09-01. Faculty of Agriculture, Kyushu University バージョン :

権利関係 : 


\title{
Effects of Rice Straw Application on Methane Emission from Rice Paddy Fields
}

\author{
Su-Hun KIM ${ }^{1}$, Jae-Han LEE ${ }^{1}$, Ji-Sun LIM ${ }^{1}$, Yoshiyuki SHINOGI ${ }^{2}$, \\ Chang-Hoon $\mathrm{Lee}^{3 *}$ and Taek-Keun $\mathrm{OH}^{1 *}$ \\ Science for Bioproduction Environment, Faculty of Agriculture, Kyushu University, \\ Hakozaki 6-10-1, Higashi-ku, Fukuoka city 812-8581, Japan \\ (Received April 28, 2018 and accepted May 8, 2018)
}

\begin{abstract}
Methane emission in soil is caused by the decomposition of organic matter under highly anaerobic conditions. Rice paddy fields are a major source of methane emission, resulting from biological and physicochemical processes affected by various factors such as the agricultural techniques, climate, and soil properties. To evaluate the roles of soil particle, rice straw application and plowing time on methane production from rice paddy, methane emissions during the rice cultivation season were investigated in two different soil textures (sandy clay loam, sandy loam). Treatments of each soil were divided into NPK only (non organic treatment) and tillage after rice straw application. The methane emission flux in the rice straw application treatment was recorded, $4.36 \mathrm{~kg} \mathrm{ha}^{-1}$ day $^{-1}$ in sandy loam and $4.85 \mathrm{~kg} \mathrm{ha}^{-1}$ day $^{-1}$ in sandy clay loam. In case of NPK only treatment, $3.30 \mathrm{~kg} \mathrm{ha}^{-1}$ day $^{-1}$ in sandy loam and $3.20 \mathrm{~kg} \mathrm{ha}^{-1}$ day $^{-1}$ in sandy clay loam. As a result, increase of methane emission by rice straw application was higher in sandy clay loam soil than in sandy loam soil.
\end{abstract}

Key words: methane emission, rice paddy, rice straw, soil texture

\section{INTRODUCTION}

Since the first commitment period under the Kyoto Protocol, the need for reduction and management of greenhouse gases (GHG) in the Parties to the Convention has increased. The Korean government has also implemented the 'Low Carbon Green Growth Basic Law' (10, 4) to build a response system to climate change. It also committed to a reduction in greenhouse gas emissions by 37\% compared to Business As Usual (BAU) by 2030, and the Ministry of Agriculture decided to implement a target for emission reduction by $7.4 \%$ (RDA, 2010). Methane accounts for the bulk of the greenhouse gas emissions from paddy soils, and is the second most important greenhouse gas after carbon dioxide as it contributes 21 times higher to warming than that of carbon dioxide (IPCC, 2001). In order to stabilize concentrations at present day levels an immediate reduction in global anthropogenic emissions by $15-20 \%$ would be necessary (Houghton et al., 1990).

Methane production is known to be influenced by organic matter, a substrate of methanogenic bacteria, soil redox potential and soil temperature (Minami, 1994). Methane emissions vary widely depending on the area, the time of measurement, the soil organic matter content, rice variety, and the cultivation period (Neue, 1993). According to Shin et al. (2003), the application of rice

${ }^{1}$ Department of Bio-Environmental Chemistry, College of Agriculture and Life science, Chungnam National University, Daejeon 305-764, Korea

${ }^{2}$ Science for Bioproduction Environment, Faculty of Agriculture, Kyushu University, Hakozaki 6-10-1, Higashi-ku, Fukuoka city 812-8581, Japan

Division of Soil and Fertilizer, National Academy of Agricultural Science, RDA, Wanju, Korea

* Corresponding author (E-mail: chlee915@korea.kr) (C. H. Lee)

* Corresponding author (E-mail: ok5382@cnu.ac.kr) (T. K. OH) straw with $5 \mathrm{Mg} \mathrm{ha}^{-1}$ in the flooded soils increased the methane emission by 1.4-1.9 times compared to the chemical fertilizer treatment. Previous studies have focused on anthropogenic factors such as water management and the effects of applied organic species, varieties and nitrogen fertilizers (Kim et al., 2002; Ko et al., 1998; Lee et al., 2005). This study was conducted to investigate the effects of soil particle distribution and organic matter application (rice straw) on methane emissions from paddy soils.

\section{MATERIALS AND METHODS}

\section{Rice cultivation management}

The experiment was conducted in the agronomy fields of Juk-dong (36 $22^{\circ} 20.4^{\prime \prime} \mathrm{N}, 127^{\circ} 19^{\prime} 52.0^{\prime \prime} \mathrm{E}$ ) and Noeun-dong (36 $22^{\prime} 23.7^{\prime \prime} \mathrm{N}, 127^{\circ} 19^{\prime} 39.5$ ”E), Yuseonggu, Daejeon City, South Korea in 2016. Two fields with different soil textures (sandy loam [SL] and sandy clay loam [SCL]) were used as experimental plots $(5 \mathrm{~m} \times 15 \mathrm{~m})$. To confirm the effect of methane emission on the application of organic matter, rice straw was used and applied at about $8 \mathrm{Mg} \mathrm{ha}^{-1}$ immediately after harvesting in autumn of last year. Each area was divided into control plot with no rice straw (NPK only) and tillage plot after rice straw application (RS). Chemical fertilizers were distributed uniformly to all treatments at $\mathrm{N}-\mathrm{P}_{2} \mathrm{O}_{5}-\mathrm{K}_{2} \mathrm{O}=90-45-57 \mathrm{~kg}$ $\mathrm{ha}^{-1}$. The total cultivation period was 132 days, and 21day-old rice (Sindongjinbyeo cultivar, Mid-late maturing one) seedlings were transplanted to flooded soil. To keep the soil conditions in a reduced state, irrigation water was controlled during the cropping season and the flooding was maintained until the harvest.

\section{Gas sampling and analysis}

The closed-chamber method was used to estimate methane flux from the soil during the cultivation period. 
Gas collecting chambers $(60 \times 60 \times 120 \mathrm{~cm})$ made of acrylic material were placed in each plot (Shin and Kim, 1994). During the rice cultivation period, gas sampling was performed every 7 days from the transplant to harvest stage, and additional sampling was performed considering the weather conditions. The gas sampling time was between 11:00 am and 12:00 am and the chamber was closed for 30 minutes (Pramanik and Kim, 2014). Before and after closing, gas samples were collected in polypropylene $60 \mathrm{ml}$ syringes.

Methane concentration in the gas samples was measured using gas chromatography with an Agilent 6890N system equipped with fused silica capillary column (30 $\mathrm{m} \times 0.53 \mathrm{~mm})$ and a flame ionization detector (FID). The oven and detector temperature were adjusted to $100^{\circ} \mathrm{C}$ and $250^{\circ} \mathrm{C}$, respectively. Hydrogen $\left(\mathrm{H}_{2}\right)$ and nitrogen $\left(\mathrm{N}_{2}\right)$ were used as the burning and carrier gases, respectively.

The Methane emission rate from the soil was calculated based on the increase in methane concentration per unit surface area of the chamber within a specific time interval. A closed-chamber equation (Rolston, 1986) was used to estimate the methane flux as follows.

$$
F=\rho \times\left(\frac{V}{A} \times \frac{\Delta c}{\Delta t} \times \frac{273}{T}\right)
$$

where, $\mathrm{F}$ is the methane flux $\left(\mathrm{mg} \mathrm{m}^{-2} \mathrm{~h}^{-1}\right), \rho$ is the methane gas density $\left(0.714 \mathrm{mg} \mathrm{cm}^{-3}\right), A$ is the area of the chamber $\left(\mathrm{m}^{2}\right), V$ is the volume of chamber $\left(\mathrm{m}^{3}\right), \Delta c / \Delta t$ is the rate of increase in methane gas concentration (ppmv), $\mathrm{T}$ is the absolute temperature $(273+$ mean temperature in ${ }^{\circ} \mathrm{C}$ ) of the chamber. The total methane flux for the entire cultivation period was computed using the following the equation (Singh et al., 1999).

$$
\text { Total } \mathrm{CH}_{4} \text { flux }=\sum_{k}^{n}\left(R_{i} \times D_{i}\right)
$$

where, $R_{i}$ is the methane flux $\left(\mathrm{g} \mathrm{m}^{-2}\right.$ day $\left.^{-1}\right)$ in ith sampling interval, $D_{i}$ is the number of days in ith sampling interval, and $n$ is the number of sampling intervals.

\section{Soil sampling and analyses}

Soil samples were collected from the surface layer $(0-15 \mathrm{~cm})$ using a zigzag pathway on the plot. The samples were air-dried and homogenized using a sieve (mesh size $<2 \mathrm{~mm}$ ). As recommended in the Soil and Plant Analysis Method of the RDA (NIAST, 2000), soil pH and electrical conductivity (EC) were measured by using a pH meter and EC meter (ORION Versa Star Pro, Thermo Scientific Inc., USA) after diluting the soil with distilled water (1: $5, \mathrm{w} / \mathrm{w})$. Furthermore, the available phosphate content was leached using the Lancaster method and quantified using ultraviolet-visible (UV-vis) spectroscopy spectrophotometer (Evolution 300, Thermo Scientific Inc., USA). Exchangeable cations were leached with $1 \mathrm{~N}$ ammonium acetate $\left(\mathrm{NH}_{4} \mathrm{OAc}\right)$ and quantified using an inductively-coupled plasma spectrometer (ICP-OES, GBC Scientific, Australia). The total carbon (T-C) and total nitrogen $(\mathrm{T}-\mathrm{N})$ were analyzed using an elemental analyzer-TCD (Flash EA 1112 series, CE Instruments, Italy).

\section{RESULTS AND DISCUSSIONS}

\section{Soil chemical properties}

The chemical properties of the paddy soils in the study are presented in Tables 1 and 2. The soil type distribution of the various test fields comprised of $21.44 \%$

\begin{tabular}{|c|c|c|c|c|c|c|c|c|c|}
\hline \multirow{2}{*}{ Soil Texture } & \multirow{2}{*}{ Treatment } & \multirow{2}{*}{$\begin{array}{c}\mathrm{pH} \\
(1: 5)\end{array}$} & \multirow{2}{*}{$\begin{array}{c}\mathrm{EC} \\
\left(\mathrm{dS} \mathrm{m}^{-1}\right)\end{array}$} & \multirow{2}{*}{$\begin{array}{c}\mathrm{T}-\mathrm{C} \\
\left(\mathrm{g} \mathrm{kg}^{-1}\right)\end{array}$} & \multirow{2}{*}{$\begin{array}{c}\mathrm{T}-\mathrm{N} \\
\left(\mathrm{g} \mathrm{kg}^{-1}\right)\end{array}$} & \multirow{2}{*}{$\begin{array}{c}\text { Av. } \mathrm{P}_{2} \mathrm{O}_{5} \\
\left(\mathrm{mg} \mathrm{kg}^{-1}\right)\end{array}$} & \multicolumn{3}{|c|}{ Ex. Cations $\left(\mathrm{cmol}_{\mathrm{c}} \mathrm{kg}^{-1}\right)$} \\
\hline & & & & & & & $\mathrm{K}^{+}$ & $\mathrm{Ca}^{2+}$ & $\mathrm{Mg}^{2+}$ \\
\hline \multirow{2}{*}{ SCL } & NPK & 6.32 & 0.45 & 7.73 & 0.79 & 97.79 & 0.36 & 1.76 & 0.52 \\
\hline & $\mathrm{RS}$ & 6.11 & 0.52 & 9.59 & 0.95 & 126.24 & 0.35 & 1.61 & 0.62 \\
\hline \multirow{2}{*}{ SL } & NPK & 5.62 & 0.30 & 7.07 & 0.66 & 134.21 & 0.57 & 1.70 & 0.63 \\
\hline & $\mathrm{RS}$ & 5.80 & 0.33 & 8.15 & 0.88 & 143.68 & 0.58 & 1.81 & 0.67 \\
\hline
\end{tabular}

Table 1. Chemical properties in paddy soils before experiment

Abbreviation: EC, electrical conductivity; T-C, total carbon; T-N, total nitrogen; Av. $\mathrm{P}_{2} \mathrm{O}_{5}$, available phosphate; Ex. Cations, Exchangeable cations; SCL; sandy clay loam; SL, Sandy loam

\begin{tabular}{|c|c|c|c|c|c|c|c|c|c|}
\hline \multirow{2}{*}{ Soil Texture } & \multirow{2}{*}{ Treatment } & \multirow{2}{*}{$\begin{array}{c}\mathrm{pH} \\
(1: 5)\end{array}$} & \multirow{2}{*}{ 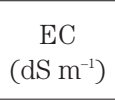 } & \multirow{2}{*}{$\begin{array}{c}\mathrm{T}-\mathrm{C} \\
\left(\mathrm{g} \mathrm{kg}^{-1}\right)\end{array}$} & \multirow{2}{*}{$\begin{array}{c}\mathrm{T}-\mathrm{N} \\
\left(\mathrm{g} \mathrm{kg}^{-1}\right)\end{array}$} & \multirow{2}{*}{$\begin{array}{l}\text { Av. } \mathrm{P}_{2} \mathrm{O}_{5} \\
\left(\mathrm{mg} \mathrm{kg} \mathrm{kg}^{-1}\right)\end{array}$} & \multicolumn{3}{|c|}{ Ex. Cations $\left(\mathrm{cmol}_{\mathrm{c}} \mathrm{kg}^{-1}\right)$} \\
\hline & & & & & & & $\mathrm{K}^{+}$ & $\mathrm{Ca}^{2+}$ & $\mathrm{Mg}^{2+}$ \\
\hline \multirow{2}{*}{ SCL } & NPK & 5.99 & 0.52 & 10.96 & 1.09 & 137.89 & 0.44 & 2.10 & 0.71 \\
\hline & $\mathrm{RS}$ & 5.94 & 0.75 & 13.63 & 1.37 & 99.39 & 0.36 & 2.05 & 0.75 \\
\hline \multirow{2}{*}{ SL } & NPK & 6.13 & 0.53 & 8.56 & 0.95 & 91.87 & 0.55 & 1.58 & 0.70 \\
\hline & $\mathrm{RS}$ & 6.23 & 1.01 & 9.96 & 1.12 & 149.22 & 0.73 & 1.73 & 0.66 \\
\hline
\end{tabular}

Table 2. Chemical properties in paddy soils after experiment

Abbreviation: EC, electrical conductivity; T-C, total carbon; T-N, total nitrogen; Av. $\mathrm{P}_{2} \mathrm{O}_{5}$, available phosphate; Ex. Cations, Exchangeable cations; SCL; sandy clay loam; SL, Sandy loam 
clay, $21.50 \%$ silt, and $57.06 \%$ sand in the SCL and 16.39\% clay, $17.33 \%$ silt, and $66.28 \%$ sand in the SL (analyzed using a hydrometer method). The $\mathrm{pH}$ of the soil before the experiment was 6.11-6.32 in SCL and 5.62-5.80 in SL. The total carbon content in the soil before the experiment was $7.73-9.59 \mathrm{~g} \mathrm{~kg}^{-1}$ in SCL and $7.07-8.15 \mathrm{~g} \mathrm{~kg}^{-1}$ in SL. The available phosphorus content was 97.79-126.24 mg kg ${ }^{-1}$ in SCL and 134.21-143.68 $\mathrm{mg} \mathrm{kg}^{-1}$ in SL. The exchangeable cation content except for potassium and soil carbon were lower than those suggested by Soil Management Practices in Upland for Environment Conservation (NIAST, 2000). The available phosphorus content was slightly higher in the SL soil. However, both soils were in the range of soil conditions that allowed normal growth of rice (Kang et al., 2014).

\section{Environmental factors}

During the cultivation period, environmental factors affecting methane emission such as precipitation, soil temperature, water temperature, and weather were investigated. The change in the temperature and precipitation from the transplanting day to the harvest are shown in Fig. 1. The average atmospheric temperature was $24.5^{\circ} \mathrm{C}$ and the total precipitation was $767 \mathrm{~mm}$. During the rainy season, rainfall intensified typically around 25-35 days after transplantation. Soil temperature was about $2-5^{\circ} \mathrm{C}$ lower than the atmospheric temperature. The difference between the atmospheric temperature and the soil temperature is due to continuous irrigation to maintain the soil in a flooded state and the shade in the soil resulting from the growing rice plants. The temperature difference was the highest at 55-70 days when the plant growth was the strongest. Soil temperature during rice cultivation period was between $20-30^{\circ} \mathrm{C}$, which is suitable for methane production (Yamane and Sato, 1964).

\section{Comparison of methane emissions \\ (1) Methane emission trends during cultivation period}

The methane emission trend in each field during the rice cultivation season is shown in Figs. 2 and 3. Methane production commenced at around 7 days after transplanting and gradually increased. The maximum amount

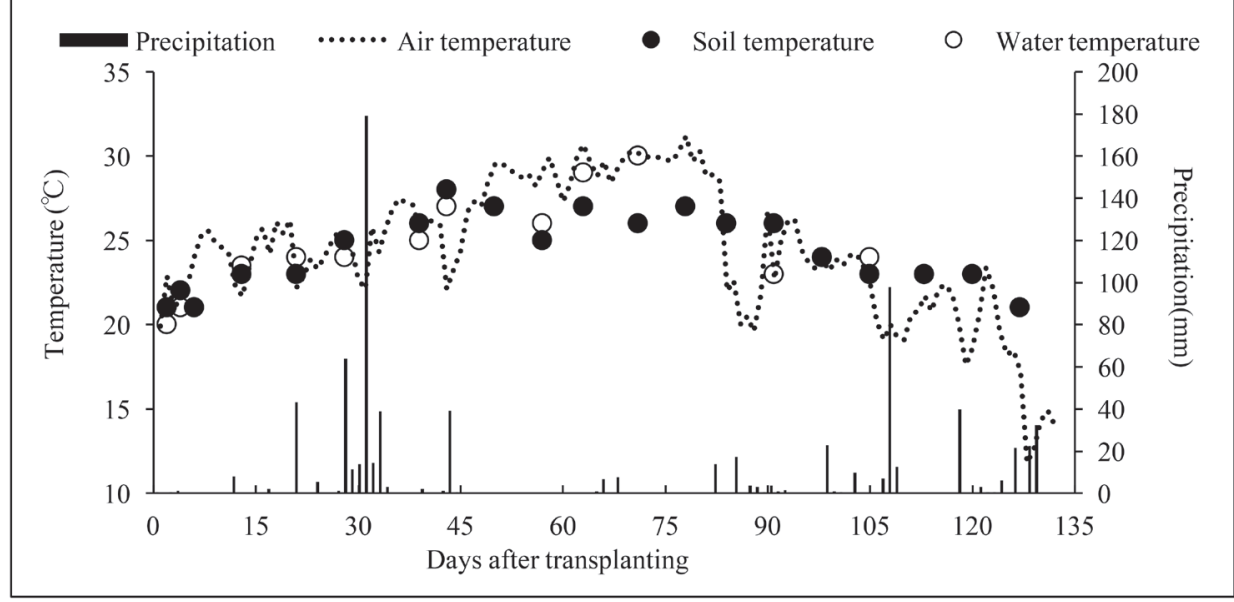

Fig. 1. Temperature change and precipitation during cultivation period.

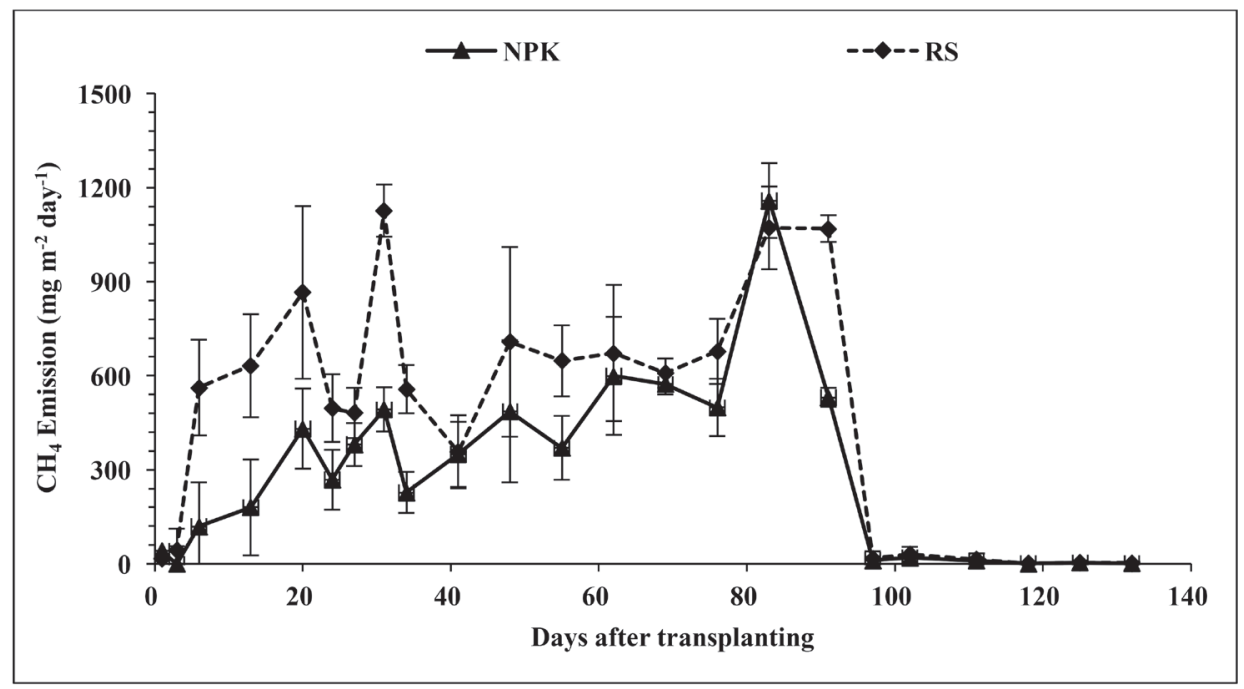

Abbreviation: NPK, N- $\mathrm{P}_{2} \mathrm{O}_{5}-\mathrm{K}_{2} \mathrm{O}$; RS, rice straw application, SCL, sandy clay loam

Fig. 2. $\mathrm{CH}_{4}$ emission rates change in SCL field during cultivation period. 


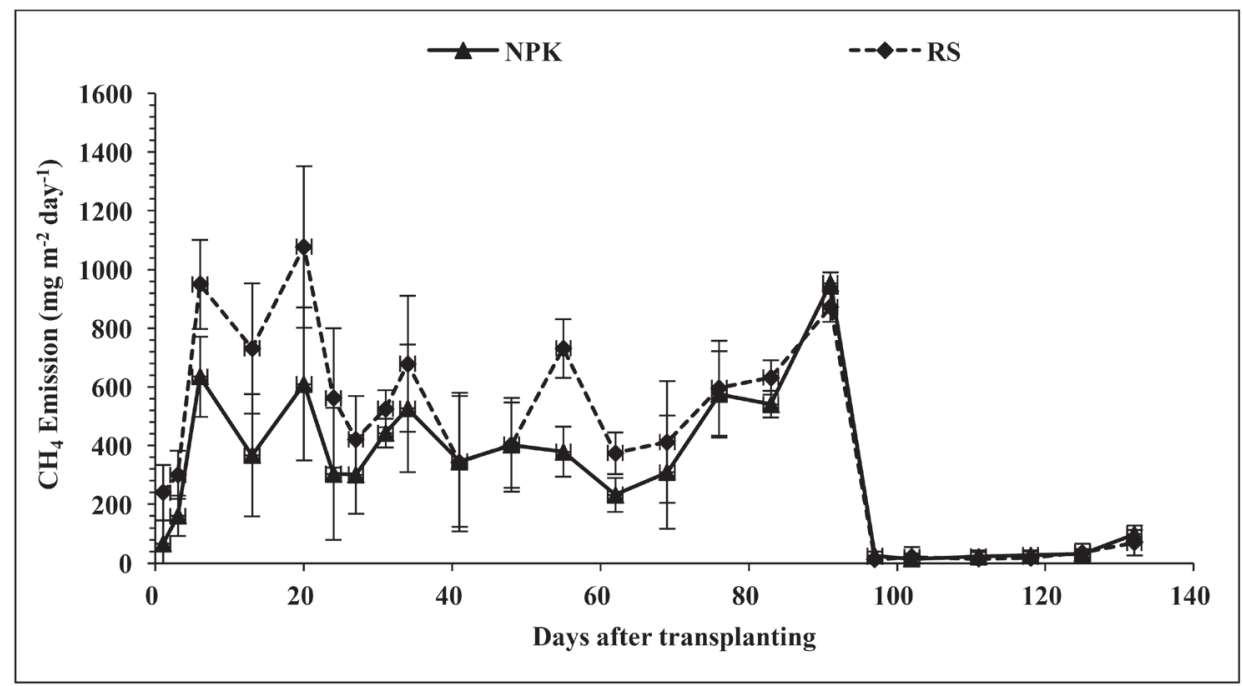

Abbreviation: NPK, $\mathrm{N}-\mathrm{P}_{2} \mathrm{O}_{5}-\mathrm{K}_{2} \mathrm{O}$; RS, rice straw application, SL, sandy loam

Fig. 3. $\mathrm{CH}_{4}$ emission rates change in SL field during cultivation period.

of methane emission was observed at around 20 days after transplanting. The amount of methane produced varied depending on soil texture and rice straw application. Methane emission increased rapidly during the early stages of growth in the sandy loam soil. These results are similar to those reported by Cho et al. (2016). When rice straw was used, both experimental fields tended to show higher overall methane emission than no rice straw application. After 90 days of transplanting, methane emission levels decreased regardless of rice straw application and the soil texture.

\section{(2) Daily average emission rate}

During the cultivation period, the daily average daily emission rates per unit area in SCL were $3.20 \mathrm{~kg} \mathrm{ha}^{-1}$ day $^{-1}$ for NPK only and $4.85 \mathrm{~kg} \mathrm{ha}^{-1}$ day $^{-1}$ for tillage after rice straw application (Fig. 4). In the case of the sandy loam, the average daily emission rates were $3.30 \mathrm{~kg} \mathrm{ha}^{-1}$ day $^{-1}$ for NPK only and $4.36 \mathrm{~kg} \mathrm{ha}^{-1}$ day $^{-1}$ for tillage after rice straw application (Fig. 5). Although the total carbon content of SL soil was lower than that of SCL soil, daily average emission rate of the SL was higher in NPK only treatment. In terms of emissions from use of rice straw, sandy loam increased methane emissions by $32.12 \%$ and sandy clay loam increased by $51.56 \%$ Based on the results of this study, It can be seen that the methane emission level is higher when the organic matter is treated in relatively clayey soils.

\section{CONCLUSIONS}

The purpose of this study was to compare methane emission based on the soil texture in paddy soils and the application of rice straw. Soil texture studied were sandy clay loam and sandy loam. Chemical fertilizers applied to each plot was $\mathrm{N}-\mathrm{P}_{2} \mathrm{O}_{5}-\mathrm{K}_{2} \mathrm{O}=90-45-57 \mathrm{~kg} \mathrm{ha}^{-1}$. Irrigation management maintained constant flooding during the cultivation season. Each field was divided:

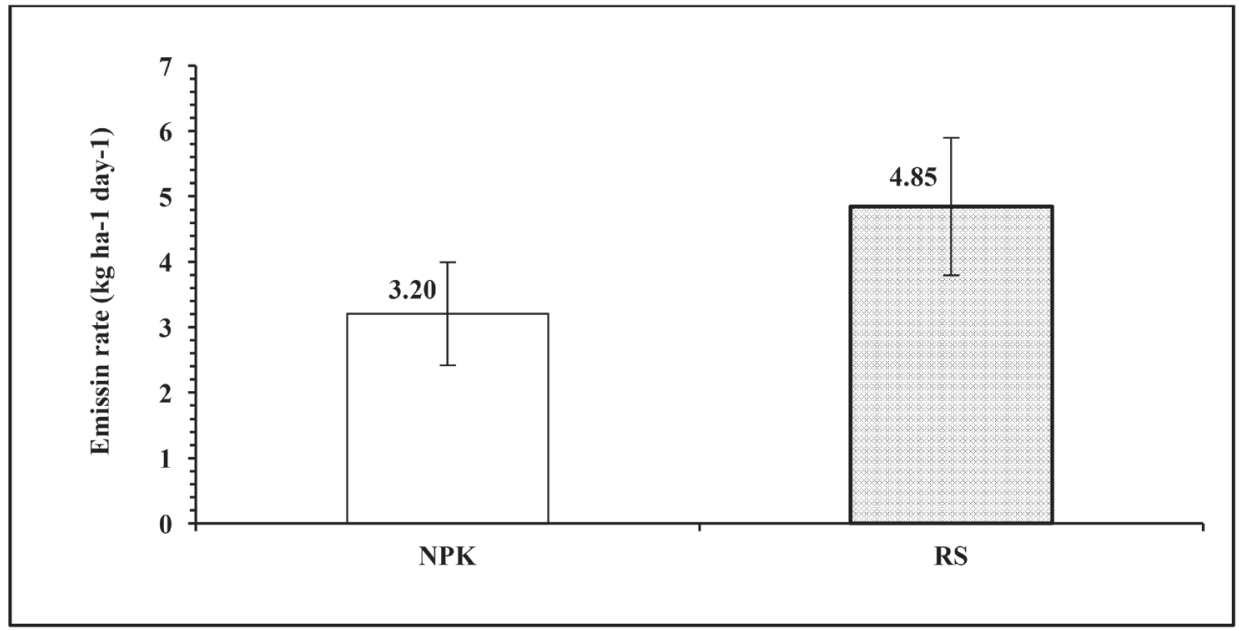

Abbreviation: NPK, N- $\mathrm{P}_{2} \mathrm{O}_{5}-\mathrm{K}_{2} \mathrm{O} ; \mathrm{RS}$, rice straw application, SCL, sandy clay loam

Fig. 4. Daily average $\mathrm{CH}_{4}$ flux per hectare in SCL field during cultivation period. 


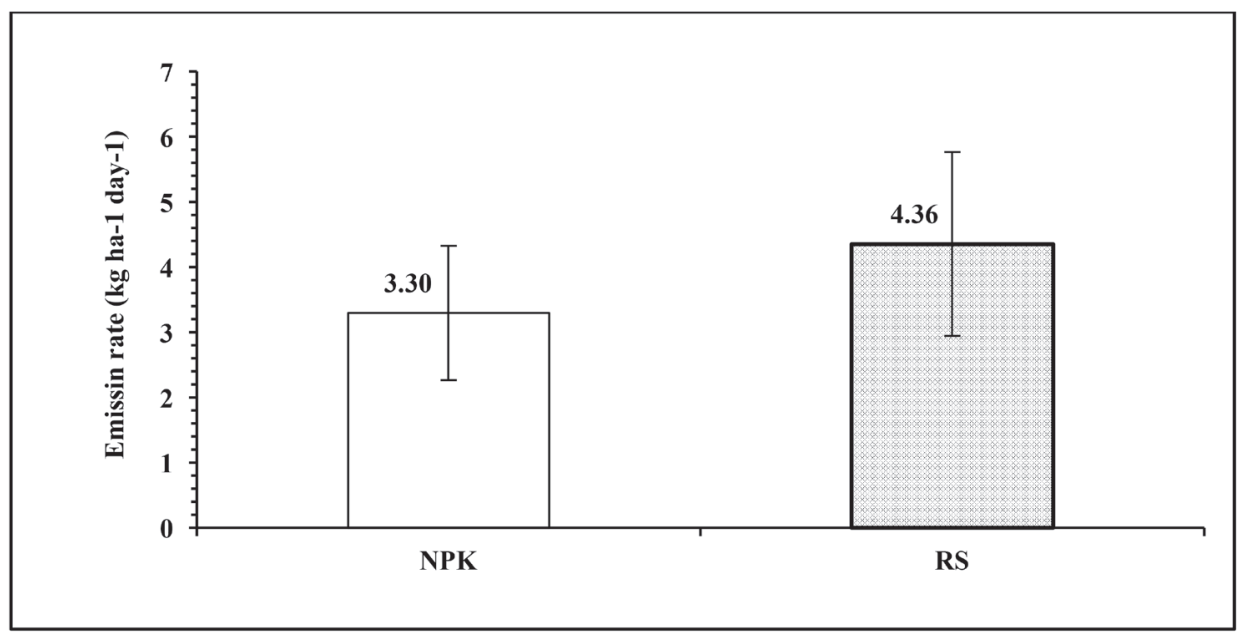

Abbreviation: NPK, N- $\mathrm{P}_{2} \mathrm{O}_{5}-\mathrm{K}_{2} \mathrm{O}$; RS, rice straw application, SL, sandy loam

Fig. 5. Daily average $\mathrm{CH}_{4}$ flux per hectare in SL field during cultivation period.

control without rice straw and tillage after rice straw application. Prior to the experiment, the paddy soils possessed chemical properties that allowed them to grow normally. Methane emission increased from about 20 days after transplanting. Especially during the early stages of growth, the emission rate increased rapidly in rice straw treatments. After 90 days of transplantation, methane emission was almost not recorded in all the treatments. The daily average emission rate during cultivation period was higher in rice straw treatment and increase of emission rate was relatively higher in relatively clayey soils.

\section{AUTHOR CONTRIBUTIONS}

Su-Hun KIM, Ji-Sun LIM and Jae-Han LEE carried out analysis and interpretation of data. Yoshiyuki SHINOGI verified the data. Taek-Keun $\mathrm{OH}$ and ChangHoon Lee supervised the project and wrote the paper. All authors commented on the manuscript.

\section{ACKNOWLEDGEMENTS}

This work was carried out with the support of the "Cooperative Research Program for Agriculture Science \& Technology Development (Project No. PJ011855052018)," Rural Development Administration, Republic of Korea.

\section{REFERENCES}

Cho, H. S., Seo, M. C., Kim, J. H., Sang, W. g., Shin, P., Lee, G. H., 2016 Effect of Soil Texture and Tillage Method on Rice Yield and Methane Emission during Rice Cultivation in Paddy Soil. Korean Journal of Soil Science and Fertilizer 49(5): 564571 [in Korean]

IPCC (Intergovernmental Panel on Climate Change), 2001. In: McCarthy, J. J., Canziani, O. F., Leary, N. A., Dokken, D. J., White, K. S. (Eds.), Climate Change Impacts, Adaptation and Vulnerability. Cambridge University Press, Cambridge

J. T. Houghton, G. J. Jenkins and J. J. Ephraums, 1990 Climate change: the IPCC scientific assessment. Cambridge University
Press, Cambridge, Great Britain, New York, NY, USA and Melbourne, Australia

Kang, S. S., Kim, M. S., Kong, M. S., Chae, M. J., Sonn, Y. K., Lee, C. H., Kim, Y. H., Lee, D. B., 2014 Setting up The Optimum Ranges of Soil Chemical Properties According to Agricultural Land Use. Korean Journal of Soil Science and Fertilizer, 120-120 [in Korean]

Kim, G. Y., Park, S. I., Song, B. H., Shin, Y. K., 2002 Emission characteristics of methane and nitrous oxide by management of water and nutrient in a rice paddy soil. Korean Journal of Environmental Agriculture 21(2): 136-143 [in Korean]

Ko, J. Y., Kang, H. W., Kang, U. G., Park, H. M., Lim, D. K., Park, K. B., 1998 The effects of nitrogen fertilizers and cultural patterns on methane emission from rice paddy fields. Korean Journal of Environmental Agriculture 17(3): 227-233 [in Korean]

Ko, J. Y., Lee, J. S., Woo, K. S., Song, S. B., Kang, J. R., Seo, M. C., Kwak, D. Y., Oh, B. G., Nam, M. H., 2011 Effects of Soil Organic Matter Contents, Paddy Types and Agricultural Climatic Zone on CH4 Emissions from Rice Paddy Field. Korean Journal of Soil Science and Fertilizer 44(5): 887-894 [in Korean]

Lee, K. B., Kim, J. G., Park, C. W., Shin, Y. K., Lee, D. B., Kim, J. D., 2005 Effect of irrigation water depth on greenhouse gas emission in paddy field. Korean Journal of Soil Science and Fertilizer [in Korean]

Minami, K., 1994 Methane from rice production. Fertilizer research 37(3): 167-179

Neue, H. -U., 1993. Methane emission from rice fields. Bioscience 43(7): 466-474

NIAST, 2000a Analytical methods of soil and plant. National institute of Agricultural Science and Technology. RDA, Suwon, Korea [in Korean]

NIAST, 2000b Soil Management Practices in Upland for Environment Conservation. RDA, Suwon, Korea [in Korean]

Pramanik, P., Kim, P. J., 2014 Evaluating changes in cellulolytic bacterial population to explain methane emissions from airdried and composted manure treated rice paddy soils. Science of the Total Environment 470: 1307-1312

RDA, 2003 Standard measurement and analysis in agricultural research and development. RDA, Suwon, Korea [in Korean]

RDA, 2010 Calculation of greenhouse gas emission in agricultural sector for 2020 and its response measures for national allocation

Rolston, D. E, 1986 Methods of Soil Analysis: Part 1—Physical and Mineralogical Methods, Soil Science Society of America, Madison. pp. 1103-1119

Shin, Y. K., Kim, K. S., 1994 Methods for measurement of meth- 
ane and nitrous oxide emissions from agricultural fields. Korean Journal of Environmental Agriculture 13(3): 359-372

Shin, Y. K., Lee, Y. S., Ahn, J. W., Koh, M. H., Eom, K. C., 2003 Seasonal change of rice-mediated methane emission from a rice paddy under different water management and organic amendments. Korean Journal of Soil Science and Fertilizer 36(1): $41-49$
Singh, S., Singh, J., Kashyap, A., 1999 Methane flux from irrigated rice fields in relation to crop growth and N-fertilization. Soil Biology and Biochemistry 31(9): 1219-1228

Yamane, I., Sato, K., 1964. Decomposition of glucose and gas formation in flooded soil. Soil Science and Plant Nutrition 10(3): $35-41$ 